e-ISSN: 2721-3013, p-ISSN: 2721-3005

DOI: https://doi.org/10.38035/jafm.v1i3

Received: 5 May 2020, Revised: 16 May 2020, Publish: 10 July 2020 https://creativecommons.org/licenses/by/4.0/

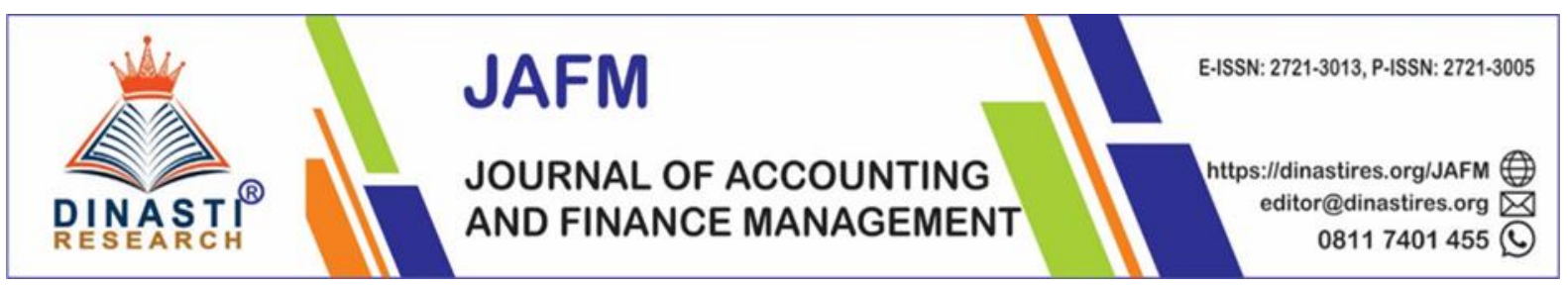

\title{
The Model of Employee Satisfaction: A Human Resources Management Perspective
}

\author{
Lukman Hadi $^{*}$, Eddy Irsan Siregar ${ }^{2}$, Siti Hafnidar ${ }^{3}$ \\ 1),2),3) University Muhammadiyah Jakarta. Indonesia, email: lukmanhadi_ims@ yahoo.com \\ *Corresponding author: Lukman hadi ${ }^{1}$
}

\begin{abstract}
This study aims to examine and analyze the influence of jobinvolvement, career development, and compensation on job satisfaction. The sampling method uses Proportionate Random Sampling. Data were taken directly using questionnaire with 58 respondents of permanent employees of M2M Solutions Ltd. The method of analysis used in this study is multiple linear regression. The result of the research shows that job involvement has a positive and significant effect on job satisfaction, career development has a significant and positive effect on job satisfaction, compensation has significant and positive effect on job satisfaction. Job involvement, career development, and compensation together have a significant and positive impact on job satisfaction. This means that job satisfaction can be explained by the three independent variables of jobinvolvement $\left(\mathrm{X}_{1}\right)$, career development $\left(\mathrm{X}_{2}\right)$, and compensation $\left(\mathrm{X}_{3}\right)$. From the result of multiple regression test, compensation is the most dominant variable in affecting job satisfaction.
\end{abstract}

Keywords: Job Involvement, Career Development, Compensation, and Job Satisfaction

\section{INTRODUCTION}

Human resources are the company's most important asset because of its role as the subject of the company's policy and operational activities. Human resource management assumes that employees are the main assets of the organization that must be managed properly, so MSDM is more strategic for the organization to achieve its stated goals (Yuniarsih and Suwatno, 2011). To achieve the goal, an organization would expect the productivity of its employees. Productivity is also seen as the ability of employees to achieve the desired results, in achieving the desired results would require a positive work attitude of employees. For it is expected for the organization must be aware and create a management system that considers the factors that affect the employee's attitude to achieve the goals of the organization itself. Howell and Dipboye (1986), in Munandar (2010) view job satisfaction as the overall result of the degree of the likes or dislikes of labor to various aspects of their work. From the above understanding, that job satisfaction can be seen from the attitude to employee work that is positive, employee attitude reflects the employee's feelings towards his work. Basically, job satisfaction is individual. Everyone will have different levels of 
satisfaction in accordance with the system of values that apply to him. According Munandar (2010) job satisfaction has an impact on productivity, absence, discharge, and its impact on health. In working people need a sense of security, a sense of satisfaction, or a sense of pleasure. Employees who feel satisfied with working in general do not want to quit the organization where they work (Sapila, 2013).

Job involvement is also a factor that gives effect of job satisfaction. According to Robbins (2001) job involvement is a measure of a person psychologically to his work and regards his performance as a measure of self-esteem. Employee engagement can give a big influence on the success of a company in achieving goals. Employee engagement is expected to have a positive impact on the company by improving the performance of each employee. High levels of engagement are strongly related to the decline and lower rates of petition request. Prasetyo (2016) explains that job involvement is one of the variables that can be used to predict conditions within the organization, such as absenteeism and turnover.

In this job involvement issue, employees at M2M Solutions Ltd feels less involved in decision making and policy undertaken by the company. Usually decision-making and policy only involve Middle to Top Management. It caused some employees to start thinking that they were not considered in the company so they lowered their work engagement interest until they decided to get out of the company.

To be able to achieve achievement in accordance with the ideals and expectations of the company then the leader is required to have a policy or program addressed to employees so that each individual employee gets high levels of job satisfaction so as to contribute optimally to the company.

In the framework of increasing job satisfaction, the company can choose several ways appropriate with the situation and ability of the company, which among others is doing promotion program and compensation.

As T. Hani Handoko (2000: 155) puts it, saying "a Personnel Department improves job performance, motivation and employee satisfaction is through compensation."

M2M Solutions Ltd was established in 1993 that integrates in business services provider of equipment and supplies with promotion needs at an exhibition, such as designing and building stands and arena for exhibition, providing the necessary equipment during exhibition, decoration and display at national and international level. M2M Solutions Ltd has a vision to become an exhibition contract leader with international standards. Their mission is Wanindo Prima will offer the best "One stop exhibition service" customers will get the best service, best quality, and good value. Wanindo Prima will manage the business with professional human resources through Total Quality Management, using competitive technology, and building mutually beneficial cooperation. Customer M2M Solutions Ltd includes Garuda Indonesia, Samsung, LG, Land Rover, Indofood, Subaru, Ford, Acer, Chevrolet, Honda, Porsche, IBM, Casio, V-kool, Hyundai, Lexus, Electrolux, Huawei.

Table 1. Employee Turnover Data M2M Solutions Ltd Jakarta 2014 to 2016

\begin{tabular}{cccccc}
\hline Year & $\begin{array}{c}\text { Number of employees } \\
\text { beginning of the year }\end{array}$ & $\begin{array}{c}\text { Number of } \\
\text { outgoing } \\
\text { employees }\end{array}$ & $\begin{array}{c}\text { Number of } \\
\text { incoming } \\
\text { employees }\end{array}$ & $\begin{array}{c}\text { Number of } \\
\text { end-of-year } \\
\text { employees }\end{array}$ & $\begin{array}{c}\text { Turnover } \\
\text { rate }\end{array}$ \\
\hline 2014 & 133 & 4 & 6 & 135 & $2,96 \%$ \\
\hline 2015 & 135 & 5 & 7 & 137 & $3,65 \%$ \\
\hline 2016 & 137 & 7 & 10 & 140 & $5 \%$ \\
\hline
\end{tabular}

Source: M2M Solutions Ltd, 2017

From the table above seen that turnover at M2M Solutions Ltd Jakarta is sustainable and tends to increase from 2014 to 2016. Based on interviews for the HRD, there are several reasons for employees to leave the company, ie employees are accepted to work elsewhere, 
the employee feels that there is no appreciation for him or her, and the perceived career do not develop. In addition to the complaints about employees about the relationship of colleagues that are less supportive of carrying out the work. According to Mangkunegara (2004) that higher job satisfaction is associated with low employee turnover while less satisfied employees usually turnover higher. This indicates that there is a problem of employee job satisfaction with M2M Solutions Ltd Jakarta. From these reasons, career development factors and employee engagement play an important role. Unfair and decent compensation also makes some employees choose to move to another company.

\section{LITERATURE REVIEW Job Satisfaction}

Richard, Robert, and Gordon (2012: 312,337) assert that job satisfaction relates to a person's feelings or attitudes about the job itself, salary, promotional or educational opportunities, supervision, co-workers, workload, and so on. A similar view expressed by Mila Badriyah (2015) states that job satisfaction is the attitude or feelings of employees to the fun or unpleasant aspects of work in accordance with the assessment of each worker. Edy Sutrisno (2014: 75) quotes Handoko (1992), suggesting job satisfaction is a pleasant or unpleasant emotional state for employees looking at their work. Job satisfaction reflects one's feelings toward one's work. According Siagian (2013: 295) job satisfaction is a way of seeing a person both positive and negative about his job.

Aydogdu and Asikgil (2011) mentioned the consequences of low job satisfaction, high absenteeism, turnover, low work productivity, decision to retire early, mental and physical health decreased to feel dissatisfaction in life. These things would be very detrimental to the company if not handled immediately. High job satisfaction will certainly give a much better impact and profitable for the company.

From the perspective of society and individual employees, job satisfaction is a desirable outcome. Employees with high levels of job satisfaction tend to have better physical health, learn new job-related tasks faster, have fewer occupational accidents, make fewer complaints and lower stress levels (Luthans, 2006).

According to Hasibuan (2009) employee job satisfaction can be influenced by factors such as fair and appropriate remuneration, appropriate placement in accordance with expertise, lightness of work, atmosphere and work environment, tools that support the implementation of work, leadership attitude and leadership monotonous work or not.

Furthermore Siagian (2000: 113) states that productive employees are those who feel happy for their interests. From the theory of human resources known that there are four variables that become an indicator of whether happy employees in the work of high productivity levels, low level of absenteeism, low employee transfer rate, and high job satisfaction.

\section{Job Engagement}

According to Robbins and Coulter (2012: 377) job involvement is the level of identifying the employee with his work, actively participating in his work, and assuming his performance at work is more important to his own good. Employees with high levels of work involvement strongly recognize the right kind and pay attention to the type of work they do. High employee engagement rates have been found to be associated with fewer attendance rates and lower employee retirement rates.

Luthans (2006) define that job involvement occurs when organizational members place themselves in a physical, cognitive, and emotional role during role performance (work).

Hiriyappa (2009) defines Job Involvement as the extent to which the individual identifies himself / herself with his work, actively participates in it, and considers that his 
performance is important to his or her self-esteem. A high level of work involvement will decrease the absenteeism and resignation of employees within an organization. While low levels of work involvement will increase absenteeism and higher resignation rates within an organization.

Muchinsky (2000) "job involvement refers to the degree to which a person identifies psychologically with his or her work and the importance of work to one's self-image". The statement implies that work involvement refers to the extent to which a person identifies psychologically with his work and the importance of working for someone in his self-image.

Blau and Boal (in Kartiningsih, 2007) argues that job engagement implies a positive and complete statement of the core aspects of oneself in the work.

According to Vance (2006) job involvement is the result of personal attributes such as knowledge, skills, abilities, temperaments, attitudes, and social settings and human resource practices that directly affect employee components, processes and work context or employee performance.

Khan (in Luthans, 2006) defines engagement as a dimension of social systems, interpersonal relationships, group dynamics and between groups, and interactions with supervisors.

Job involvement becomes a force that helps workers in many forms and organizational outcomes. Diefendorff, Brown, Kamin, and Lord (in Lambert, 2008) suggest that job involvement is a key factor affecting individual outcomes and the importance of the organization.

\section{Career development}

According to Bernardin and Russell (2003: 340) career development is an organized formal effort to achieve a balance between individual career needs and organizational needs, career development is a mechanism to meet current and future organizational HR needs. In line with this Simamora (2004) argued that basically career development can be explained from two perspectives, namely internal and external. Externally, career development can be viewed as a formal approach taken by the organization to ensure that people with appropriate experience qualifications are available when needed, whereas internally, career development can be viewed as an effort / personal step to achieve their career goals. This internal perspective is in line with that of Rivai and Sagala (2009), career development is the process of improving individual work ability achieved to achieve the desired career and put forward by Rivai (2004: 290), that career development is the process of capacity building individual work achieved to achieve the desired career. Dessler (2000: 45) also defines career development including career planning seen from the internal side of a deliberate process through which a person becomes aware of the attributes related to personal care and a series of life-long steps that contribute to the fulfillment of his career.

According to I Komang A, et al (2012) career development is a personal improvement that a person undertakes to achieve a career plan and improvement by the personnel department to achieve a work plan in accordance with the path or ladder of the organization. So, no matter how good a career plans a worker has made accompanied by a reasonable and realistic career goal, the plan will not come true of systematic and programmatic career development. Since career planning is a decision taken now about things to do in the future, it means that someone who has already set a career plan, needs to take certain steps to realize the plan. The various steps that need to be taken can be taken on the initiative of the workers themselves but can also be a sponsored activity by the organization, or a combination of both. It should be emphasized that even though human resources can play a role in the development activities, the most responsible are the workers themselves because they are the ones that are most interested and who will also be able to pick and enjoy the results. This is 
one of the most fundamental principles of career development.

\section{Compensation}

In Big Indonesian Dictionary, compensation can be interpreted as compensation, remuneration in the form of money or not money given to employees in the company or organization. Meanwhile, according to experts, here are some notions of compensation: Caruth and Handlogten (2001: 2) define widespread compensation as rewards or grants given to a person for services performed, in line with that Handoko (2000: 205) defines compensation as everything that employees receive as a reward for their work. From both definitions it is generally understood that compensation is a reward or a reward for work.

Next. According to Daft (2003: 416), compensation refers to all payments of money and all goods or commodities used based on the value of money to reward employees. Bernardin (2007: 252) uses the term compensation for all forms into financial results and real benefits that workers receive as part of the relationship.

According Ardana (2012: 153), compensation is everything that is received by employees as a service for its contribution to the company or organization.

According to Swasto (2002) in Afrida, et al (2014) compensation in terms of employees is everything that employees receive in return for contributions to energy and thoughts donated to the organization.

According to Bangun (2012) in Feridan Kartika (2014) compensation is one of the important factors and is of concern to many organizations of considering and attracting qualified human resources.

According to Simamora (2004) in Afrida, et al (2014) the compensation components are divided into direct compensation and indirect compensation. Direct financial compensation consists of the pay (pay) earned by a person in the form of a wage, wages, bonus, and commission. Indirect financial compensation, also called allowances, includes all financial rewards not covered by direct compensation. Non-financial compensation consists of the satisfaction one obtains from the job itself, or from the psychological and physical environment in which the person works. This type of nonfinancial compensation includes the satisfaction gained from the execution of significant task-related tasks.

\section{Conceptual framework}

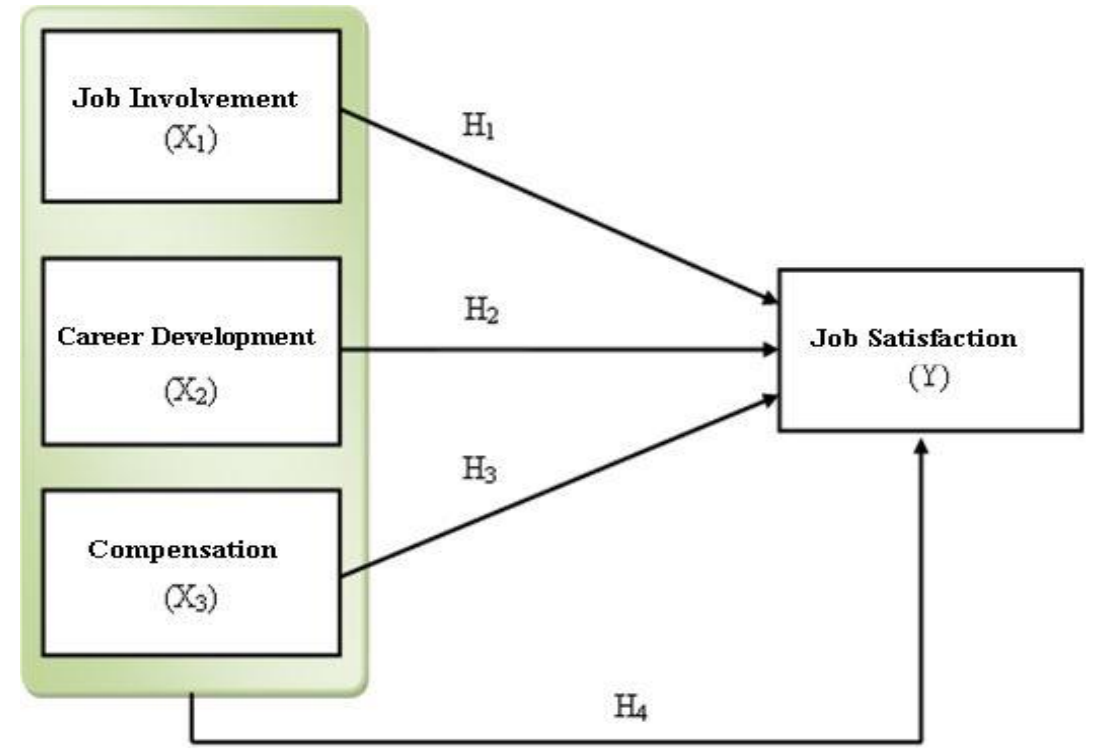

Figure 1. Conceptual Research Framework 


\section{Research Hypothesis}

1. $\mathrm{H}_{1}$ : There is an influence over job involvement in employee job satisfaction

2. $\mathrm{H}_{1}$ : There is an influence over career development on employee job satisfaction

3. $\mathrm{H}_{1}$ : There is an influence over compensation for employee job satisfaction

4. $\mathrm{H}_{1}$ : There is an influence over job involvement, career development, and compensation collectively towards employee job satisfaction

\section{METHODS}

\section{Research design}

This research is descriptive, verifikatif, and explanatory conducted through data collection in the field, the research method used is a survey, ie research aimed at assessing large and small populations by selecting and reviewing selected samples from the population to find incidence, distribution, and the relative interrelations of the variables (Kerlinger and Lee, 2000). Unit of analysis under study is permanent employees of M2M Solutions Ltd.

\section{Population}

Population of this research is permanent employee of M2M Solutions Ltd which amounted to 140 people. Sample determination in this research using Slovin formula as follows:

$$
n=\frac{N}{1+N \alpha^{2}} \quad \longrightarrow \quad \mathrm{n}=\frac{140}{1+140(0.10)^{2}}=58.33=58
$$

Description:

$$
\begin{array}{ll}
\mathrm{n} & =\text { number of samples } \\
\mathrm{N} & =\text { number of populations } \\
\alpha & =\text { error rate }
\end{array}
$$

Of the total employees of M2M Solutions Ltd, based on the slovin formula then the number of permanent employees who become samples or respondents in this study are as many as 58 people. The technique of determining the sample used is proportional random sampling.

\section{Data collection technique Instrument testing}

a. Validity test

To measure the level of validity of this study using Pearson correlation (Pearson Correlation) is to correlate the score of each item statement by the total score. This test was conducted to see if the statement items contained in this research instrument measured the measured constructs (now, 2006: 207).

The Pearson correlation formula used is:

$$
r_{x y}=\frac{n\left(\sum X Y\right)-\left(( \sum X ) \left(\left(\sum Y\right)\right.\right.}{\sqrt{ } \operatorname{nn}\left(\left(\sum X^{2}\right)-\left(\left(\sum X\right)^{2} \mid n\left(\left(\sum Y^{2}\right)-\left(\left(\sum Y\right)^{2}\right]\right.\right.\right.}
$$

Description:

$\mathrm{r}_{\mathrm{xy}}=$ correlation coefficient

$\mathrm{X}=$ score of instrument item used

$\mathrm{Y}=$ score all instrument items in the variable

$\mathrm{n}=$ number of respondents in the trial of the instrument 


\section{b. Test Reliability}

In this research, reliability tests are done by calculating the coefficient of cronbach alpha from each item in a variable. According to Sekaran (2006: 311), measurement scales with alpha coefficient less than 0.6 means bad, 0.7 means acceptable whereas more than 0.8 means either.

\section{FINDINGS AND DISCUSSION}

Classic assumption test

a. Normality Test

Normality tests is a test of the normal distribution of data. The use of the normality tests because of the parametric statistical analysis, the assumption that must be possessed by the data is that the data must be normally distributed.

b. Heteroscedasticity Test

c. Normality tests is a test of the normal distribution of data. The use of the normality tests because of the parametric statistical analysis, the assumption that must be possessed by the data is that the data must be normally distributed.

d. Multicollinearity Test

This test aims to test whether the regression model found a correlation between independent variables (independent). A good regression model should not be correlated with independent variables. If independent variables are correlated, these variables are not orthogonal (Ghozali 2007: 91).

e. Autocorrelation Test

The autocorrelation test is an assumption test of the regression where the dependent variable is not correlated with itself. The purpose of correlation between self is that the value of the dependent variable is not related to the value of the variable itself, either the value of the previous variable or the value of the period afterwards (Santosa and Ashari, 2005: 240).

\section{DISCUSSION}

1. The first hypothesis: $\beta \neq 0$ (There is influence of job involvement to job satisfaction of permanent employee of M2M Solutions Ltd).

a. There is a positive or unidirectional relationship between job involvement variable $\left(\mathrm{X}_{1}\right)$ and Job satisfaction variable (Y), which is indicated by a positive correlation coefficient (r) of 0.592, the level of influence is at a moderate level.

b. Significant probability values smaller than $\alpha$ or $0.000<0.050$ thus there is significant influence between job involvement variable $\left(\mathrm{X}_{1}\right)$ with job satisfaction variable $(\mathrm{Y})$;

c. By regression test known that regression equation for influence of work involvement variable $\left(\mathrm{X}_{1}\right)$ to job satisfaction $(\mathrm{Y})$ that is $\mathrm{Y}=14,397+0,0407 \mathrm{X}$. From the result of this equation can be interpreted that job involvement variable $\left(\mathrm{X}_{1}\right)$ brings influence equal to 0,407 units to satisfaction with work. If there is an increase in work involvement in one unit then there will be also increased from job satisfaction with 0.407 units;

d. The simple regression significance test using t-test resulted the conclusion that $\mathrm{H} 0$ was rejected because the value of t-test $(5,742)$ was bigger than t-table $(2,001)$ thus H1 accepted that there was influence of job involvement on the job satisfaction. Furthermore, because the significance coefficient of 0.000 is smaller than the value of $\alpha$ (0.05), the effect is significant.

e. The value of coefficient of determination of work involvement variable $\left(\mathrm{X}_{1}\right)$ of 0.351 indicates that the contribution to job involvement variable $\left(\mathrm{X}_{1}\right)$ is $35,1 \%$ to job 
satisfaction (Y) while other variables influence work culture, leadership, organizational climate, work load and others set at $64.9 \%$.

From result of hypothesis test can be seen that influence over job involvement variable (X1) with job satisfaction variable (Y) is positive / unidirectional and level is categorized low. Judging from $\mathrm{r}^{2}$, the value of the score is only $35.1 \%$ of the work involvement variables $\left(\mathrm{X}_{1}\right)$ can affect the variability of job satisfaction value (Y). Nevertheless, increased employment engagement will continue to increase the value of job satisfaction as demonstrated by the formula regression equation.

The results of this research indicate that job involvement has an effect on the job satisfaction. The implication of this empirical research fact indicates that the higher the job involvement the better the job satisfaction.

The results of this study in accordance with the results of research Rini and L. Suhairi Haizima (2013) states that job involvement has a significant effect on the job satisfaction.Aryaningtyas and Lieli (2013) also states that job involvement has a positive and significant impact on job satisfaction. Aris Archandar (2010) and Ridwan (2014) stated that job involvement has a positive and significant influence on job satisfaction.

\section{Second hypothesis: $\beta \neq 0$ (There is an influence of career development on employee job satisfaction fixed at PT.Wanindo Prima Jakarta).}

a. There is a positive or unidirectional influence between career development variables $\left(\mathrm{X}_{2}\right)$ with job satisfaction variable $(\mathrm{Y})$, which is shown by a positive correlation coefficient ( $\mathrm{r}$ ) of 0.559 , the level of influence is at a moderate level.

b. The probability value of significance is smaller than $\alpha$ or $0.000<0.050$ thus there is a significant influence between career development variables $\left(\mathrm{X}_{2}\right)$ with job satisfaction variable (Y);

c. By regression test known that regression equation for the influence of career development variable $\left(\mathrm{X}_{2}\right)$ to job satisfaction $(\mathrm{Y})$ is $\mathrm{Y}=18,304+0,449 \mathrm{X}$. From the results of this equation can be interpreted that career development variables $\left(\mathrm{X}_{2}\right)$ bring the effect of 0.449 units to job satisfaction. If there is an increase in career development of one unit then there will be also increased from job satisfaction with 0.449 units;

$\mathrm{d}$. The simple regression significance test using t-test resulted the conclusion that $\mathrm{HO}$ is rejected because the value of t-test $(5,264)$ is bigger than t-table $(2,001)$ thus H1 accepted that there is influence of career development on the job satisfaction. Furthermore, because the significance coefficient of 0.000 is smaller than the value of $\alpha$ (0.05), the effect is significant.

e. The value of coefficient of determination of career development variable $\left(\mathrm{X}_{2}\right)$ is 0,312 shows that contribution to career development variable $\left(\mathrm{X}_{2}\right)$ is $31,2 \%$ to job satisfaction (Y) while other variables influence work culture, leadership, organizational climate, work load and others contributed by $68.8 \%$.

From the hypothesis test results can be seen that the influence over career development variables $\left(\mathrm{X}_{2}\right)$ with job satisfaction variable $(\mathrm{Y})$ is positive / unidirectional and the level is categorized low. Judging from the value of $\mathrm{r} 2$ value is only $31.2 \%$ course career development variables $\left(\mathrm{X}_{2}\right)$ can affect the variability of job satisfaction value $(\mathrm{Y})$. Nevertheless, the improvement in career development continues to increase the value of job satisfaction as demonstrated by the regression equation formula.

The results of this research indicate that career development has an effect on the job satisfaction. The implications of this empirical research fact indicate that the better the career development the higher the job satisfaction.

The results of this study in accordance with the results of research conducted by Nugroho and Kunartinah (2012) showed a positive and significant influence between career development 
and job satisfaction. Kurniawan (2015) states career development has a significant effect on the job satisfaction. Wahda and Handaru (2015) and Ichwan Prastoyo (2015) also stated that there is a positive and significant influence between career development and job satisfaction. This means that by increasing employee career development, employees will have high job satisfaction.

3. The third hypothesis: $\beta \neq 0$ (There is a compensation effect on job satisfaction of permanent employees of M2M Solutions Ltd)

a. There is a positive or unidirectional influence between the compensation variable $\left(\mathrm{X}_{3}\right)$ and Job satisfaction variable $(\mathrm{Y})$, which is indicated by a positive correlation coefficient (r) of 0.479 , the level of influence is at a low level.

b. The probability value of significance is smaller than $\alpha$ or $0.000<0.050$ thus there is a significant relationship between the compensation variable $\left(\mathrm{X}_{3}\right)$ with the job satisfaction variable $(\mathrm{Y})$;

c. By regression test, it is known that the regression equation for the influence of the compensation variable $\left(\mathrm{X}_{3}\right)$ on job satisfaction $(\mathrm{Y})$ is $\mathrm{Y}=19,095+0,568 \mathrm{X}$. From the result of this equation it can be interpreted that the compensation variable $\left(\mathrm{X}_{3}\right)$ has an effect of 0.568 units to job satisfaction. If there is an increase in compensation for one unit then there will be also increased from job satisfaction with 0.568 units;

d. The simple regression significance test using t-test resulted the conclusion that $\mathrm{H}_{0}$ is rejected because the value of t-test $(4,262)$ is bigger than t-table $(2,001)$ thus $\mathrm{H} 1$ accepted that there is influence of compensation for job satisfaction. Furthermore, because the significance coefficient of 0.000 is smaller than the value of $\alpha(0.05)$, the effect is significant.

e. The value of coefficient of determination of compensation variable $\left(\mathrm{X}_{3}\right)$ equals to 0,229 shows that contribution to variable of compensation $\left(\mathrm{X}_{3}\right)$ equals to $22,9 \%$ to job satisfaction (Y) while influence of other variables like work culture, leadership, organizational climate, work load and others of $77.1 \%$.

From result of hypothesis test can be seen that influence over variable of compensation $\left(\mathrm{X}_{3}\right)$ with job satisfaction variable $(\mathrm{Y})$ is positive / unidirectional and level is categorized low. Judging from $\mathrm{r}^{2}$ then the values of only $22.9 \%$ value of the compensation variable $\left(\mathrm{X}_{3}\right)$ can affect the variability of job satisfaction values $(\mathrm{Y})$. Nevertheless, the increase in compensation continues to increase the value of job satisfaction as demonstrated by the formula regression equation.

The results of this research indicate that the compensation effect on job satisfaction The implications of this empirical research facts indicate that the higher the compensation the better the job satisfaction. According to Andri Gunawan (2017) compensation has a significant effect on the job satisfaction. Kenny Yulianto Kurniawan (2015) found that compensation affects employee job satisfaction. This means that by increasing employee compensation, employees will have high job satisfaction. Research Yusron, Toni, and Anggun (2015) also found that compensation has a positive and significant effect on employee job satisfaction.

4. Fourth hypothesis: $\beta 1 \neq \beta 2 \neq 0$ (There is influence of job involvement, career development and compensation together to job satisfaction of permanent employees of M2M Solutions Ltd).

a. There is a positive or unidirectional influence between work involvement variable $\left(\mathrm{X}_{1}\right)$, career development $\left(\mathrm{X}_{2}\right)$ and compensation $\left(\mathrm{X}_{3}\right)$ together with Job satisfaction variable (Y), which is indicated by a positive correlation coefficient (r) of 0.693 , the effect is at a moderate level. 
b. The significance probability is smaller than $\alpha$ or $0,000<0.050$ thus there is a significant relationship between job involvement variables $\mathrm{X} 1$, career development $\left(\mathrm{X}_{2}\right)$ and compensation $\left(\mathrm{X}_{3}\right)$ together with job satisfaction variable $(\mathrm{Y})$;

c. By regression test it is known that the regression equation for the influence of job involvement variable $\mathrm{X} 1$, career development $\left(\mathrm{X}_{2}\right)$ and compensation $\left(\mathrm{X}_{3}\right)$ together on job satisfaction $(\mathrm{Y})$ is $\mathrm{Y}=3,475+0,196 \mathrm{X}_{1}+0,267 \mathrm{X}_{2}+0,310 \mathrm{X}_{3}$, From result of this equation can be interpreted that job engagement variable $\left(\mathrm{X}_{1}\right)$ bring influence equal to 0,196 unit, career development variable $\left(\mathrm{X}_{2}\right)$ brings influence equals to 0,267 units and compensation $\left(\mathrm{X}_{3}\right)$ brings influence equal to 0,310 units, to job satisfaction with assumption that two other variables unchanged when one variable is altered or overall job satisfaction will increase by 0.7730 when job engagement, career development, and compensation are increased by one unit.

d. The double regression significance test using the F-test yields the conclusion that $\mathrm{H} 0$ is rejected because the value of F-test $(18,149)$ is greater than F-table $(2.75)$ thus $\mathrm{H}_{1}$ is accepted that there is influence of work involvement, career development, and compensation together equal to job satisfaction. Furthermore, because the significance coefficient of 0.000 is smaller than the value of $\alpha(0.050)$, the effect is significant.

e. The value of coefficient of determination of job involvement variable $X_{1}$, career development $\left(\mathrm{X}_{2}\right)$ and compensation (X3) 0,480 indicates that contribution of job involvement variable $X 1$, career development (X2) and compensation ( $\left.X_{3}\right) 48 \%$ to job satisfaction (Y) while the influence of other variables such as work culture, leadership, organizational climate, workload and others also determine $52 \%$.

From result of hypothesis test can be seen that the influence between job involvement variable $\left(\mathrm{X}_{1}\right)$, career development $\left(\mathrm{X}_{2}\right)$ and compensation $\left(\mathrm{X}_{3}\right)$ together with job satisfaction variable (Y) are positive / direction and level is categorized low. Viewed from $\mathrm{r}^{2}$ then the three variables can affect the variability of job satisfaction values of $48 \%$.

The results of this research indicate that job involvement, career development and compensation have an effect on job satisfaction. This relationship can be interpreted that changes in job satisfaction are influenced by the variables of work involvement, career development and compensation. The results of this study also found test together that the compensation variable is the most dominant variable in affecting job satisfaction.

\section{CONCLUSIONS AND RECOMMENDATIONS}

\section{Conclusion}

1. The influence of job involvement on the job satisfaction with M2M Solutions Ltd Jakarta is significant. This is indicated by $\mathrm{t}$ count $(5,742)>\mathrm{t}$ table $(2,001)$, with regression equation $\mathrm{Y}=14,397+0.407 \mathrm{X}_{1}$, so it can be concluded that there is influence between job involvement with job satisfaction at M2M Solutions Ltd Jakarta.

2. The influence of career development on the job satisfaction with M2M Solutions Ltd Jakarta is significant. This is indicated by the result of $t$ count $(5,264)>t$ table $(2,001)$, with regression equation $\mathrm{Y}=18,304+0.449 \mathrm{X}_{2}$, so it can be concluded that there is influence between career development with job satisfaction at M2M Solutions Ltd Jakarta.

3. Effect of compensation for employee job satisfaction with M2M Solutions Ltd Jakarta is significant. This is indicated by the result of $t$ arithmetic $(4,268)>t$ table $(2,001)$, with regression equation $\mathrm{Y}=19,095+0.568 \mathrm{X} 3$, so it can be concluded that there is influence between compensation with employee job satisfaction at M2M Solutions Ltd Jakarta.

4. The influence of job involvement, career development and compensation together affect the employee's job satisfaction at M2M Solutions Ltd Jakarta is significant. This is indicated by the result of $F$ arithmetic of $F$ and the value of $F$ tables of 2.43 , because $F$ counts $(18,149)>\mathrm{F}$ table $(2.75)$, so it can be concluded that there is influence jointly work 
involvement, career development and compensation to employee job satisfaction M2M Solutions Ltd Jakarta.

\section{Recommendations}

1. Job involvement, career development and compensation has been proven to affect employee job satisfaction at M2M Solutions Ltd Jakarta. Therefore M2M Solutions Ltd Jakarta is expected to continue to maintain job involvement, career development and compensation because it covers a very wide range of activities that are useful to increase the potential and productivity of employees at M2M Solutions Ltd Jakarta. Based on the results of research with multiple regression method, compensation is the highest variable among other variables in affecting employee job satisfaction. This can be seen from the following regression equation: $\mathrm{Y}=3,475+0,196 \mathrm{X}_{1}+0,267 \mathrm{X}_{2}+0,310 \mathrm{X}_{3}$ Compensation has the highest value of 0.310 . While work involvement has a lower value that is equal to 0.196. Thus, to improve work satisfaction should be prioritized on maintaining the compensation variable considering the mean value in the descriptive test have a high value of 4.2095 .

2. For future researchers in the future which will conduct further research development, it is expected to improve or increase the number of research variables, such as work culture variables, leadership, organizational climate, and workload. The next researcher is also suggested to improving the questions that exist on this research and increase the number of research samples in terms of affects employee job satisfaction.

\section{REFERENCES}

Anoraga, Pandji. 2001. Work Psychology. Jakarta. Adi Mahasatya

Ardana. 2012. Human Resource Management. Yogyakarta. Graha Ilmu

Arikunto, S. 2002. Research Procedures A Practice Approach. Jakarta. Rineka Cipta

As'ad. 2004. Industrial Psychology: Human Resources Series. Yogyakarta. Liberty

Aydogdu, Sinem and Baris Asikgil. 2011. An Empirical Study of the Realtionship Among Job

Satisfaction, Organizational Commitment and Turnover Invention. International Review of Marragen 7ent and Marketing Vol.1 No.3

Badriyah, Mila. 2015. Human Resource Management. Bandung. Pustaka Setia

Bernardin, H. John, dan Joyce E.A Russel. 2003. Human Resources Management (An Experimental Approach International Edition). Singapore. Mc. Graw-Hill Inc

Bernardin, John. 2007. Human Resources Management. New York. Mc. Graw-Hill Irwin

Caruth, Donald L., Gail D. Handlogten. 2001. Managing Compensation (and Understanding It Too) : Handbook For The Perplexed, Westport. CT. Greenwood Publishing Group

Cohen, A. 2003. Multiple Commitment in the Workplace : An Integrative Approach.New Jersey. Lawrence Erlbaum Associates,Inc.

Daft, Richard L. 2003. Human Resource Management. Jakarta. Erlangga

Davis, Keith and John W Newstorm. 1994. Organizational Behavior, Alih Bahasa Agus Dharma. Jakarta. Erlangga

Dessler, Gary. 2000. Human Resource Management, Translation Edition.. Jakarta. PT. Prenhallindo

Edwin B. Flippo. 2002. Personel Management, Edition VII Volume II, Translation Alponso S. Jakarta. Erlangga

Edy Sutrisno. 2014. Human Resource Management, Sixth Print. Jakarta. Pranada Media Group

Ekayadi, Septyaningsih. 2009. Influence Motivation And Career Development Of Job Satisfaction Employees At PT. Rimbajati Citrakarya 
Flippo, L. 1994. Careers in Organizations (Translation Susanto Budidharmo). Semarang. BPFE Diponegoro University

Ghozali,Imam. 2001. Application of Multivariate Analysis With SPSS Program. Semarang. BP-Diponegoro University.

Ghozali,Imam. 2007. Application of Multivariate Analysis With SPSS Program. Semarang. BP-Diponegoro University.

Gibson, Ivancevich, and Donely. 2000. Organization and Management: Structure Behavior, Translation Fourth Edition. Jakarta. Erlangga

Handoko, T.Hani. 2000. Company Organization. Yogyakarta. BPFE

Handoko, T.Hani. 2002. Management Edition 2. Yogyakarta. BPFE

Hasibuan, Malayu. SP. 2009. Human Resource Management. Jakarta: Publisher Bumi Aksara.

Hiriyappa. 2009. Organizational Behaviour. New Delhi. New Age International Publisher Irianto, Jusuf. 2001. Human Resource Management. Jakarta. Insan Cendikia

Isyanto, Puji dkk, 2013. The Effect Of Career Development On Employee Motivation. Journal of Management, April, Vol. 10, Number 3

Ivancevich, M. John. 2007. Human Resources Management, Twelve Edition. Singapore. Mc. Graw-Hill

Kadarisman. 2012. Human Resource Development Management, First Edition, First Print. Jakarta. Rajawali Press

Kartiningsih SH. 2007. Analysis of the Influence of Organizational Culture and Job Engagement Against Organizational Commitment In Improving Employee Performance. Undip Thesis.

Kerlinger, F. N. and Lee, H. B. 2000. Foundation of Behavioral Research (Fourth Edition). USA. Holt, Reinar \& Winston Inc

Luthans, Fred. 2006. Organizational Behavior Ten Edition. Yogyakarta. Andi

Madura, Jeff. 2001. Business Introduction. Jakarta. Salemba Empat.

Mangkunegara, A.P. 2000. Human Resource Management. Bandung. Rosdakarya

Mangkunegara, A.P. 2001. Human Resource Management Company, Third Print. Jakarta. PT. Rosda Karya.

Mangkunegara, A.P. 2007. Human Resource Management, Seventh Printing. Bandung. PT. Remaja Rosdakarya

Munandar. 2010. Budgeting, Work Planning, Coordination of Work and Work Supervision. Yogyakarta. BPFE Universitas Gajah Mada

Rivai, Veithzal. 2004. Human Resource Management For Companies. Jakarta. PT. Raja Grafindo Persada

Rivai, Veithzal. 2006. Leadership and Organizational Behavior Issue 2. Jakarta. PT. Raja Grafindo Persada

Rivai, Veithzal and Jauvani Sagala. 2009. Human Resource Management For Companies From Theory to Practice. Jakarta. PT. Rajagrafindo Persada

Rivai, Veithzal and Ella Sagala. 2013. Human Resource Management For Companies. Jakarta. Rajawali Pers

Robbins, Stephen. P. 1996. Organizational Behavior: Controversy Concepts, Applications, Hadyana Pudjaatmaka and Benyamin Molan's Interpretations, First Volume.. Jakarta: Prenhalindo.

Robbins, Stephen. P. 2001. Organizational Behavior: Controversy Concept, Application, Volume I Eighth Edition. Jakarta: Prenhalindo.

Robbins, Stephen P. dan Timothy A. Judge, 2008, Organizational Behavior, Issue 12 Volume 1 and 2, Jakarta: Salemba Empat. 
Santosa, Purbayu Budi and Ashari. 2005. Statistical Analysis With Microsoft Excel and SPSS. Yogyakarta. Andi

Santoso, Singgih. 2001. SPSS Versi 10 : Managing Professional Statistics. Jakarta. PT. Elex Media Komputindo

Sapila. 2013. Influence Work Motivation, Leadership And Career Development Of Job Satisfaction Employees At Education Office Pasaman District

Schultz, D \& Schultz, S. E. 1998. Psycology and Work Today : An intdroduction to Industrial and Organizational Psychology, $7^{\text {th }}$ ed. New Jersey. Prentince Hall

Sekaran, Uma. 2006. Research Methodology For Business. Jakarta. Salemba Empat

Simamora, Henry. 2004. Human Resource Management Issue 3. Yogyakarta. STIE YKPN

Simamora, Henry. 2006. Human Resource Management Issue 2. Yogyakarta. STIE YKPN

Sugiono. 2010. Qualitative Quantitative Research Methods and $R \&$ D. Bandung. Alfabeta

Sugiyono. 2012. Understanding Qualitative Research. Bandung. Alfabeta

Vance, Robert. 2006. Employee Engagement and Commitment. SHRM Foundation's Effective Practice Guidelines. United States.

Werther, William B. dan Davis, Keith. 1996. Human Resources and Personnel Management, $5^{\text {th }}$ ed. New York. Mc. Graw-Hill

Wijaya, Tony. 2009. Analysis of Research Data Using SPSS. Yogyakarta. Atma Jaya University

Yuniarsih, Tjutju and Suwatno. 2011. Human Resource Management. Bandung. Alfabeta

\section{Journal}

Agung AWS Waspodo, Rio Dharmawan, Agung Wahyu Handaru. 2017. . The Influence of Compensation, Motivation, and Career Development on Employee Job Satisfaction At PT. NIKKO CAHAYA ELECTRIC. State University of Jakarta. Journal of Indonesian Science Management Research (JRMSI), Vol.8 No. 1, Year 2017

Agus Dwi Nugroho and Kunartinah. 2012. Effect of Compensation and Career Development on Job Satisfaction with Work Motivation Mediation. Journal of Business and Economics (JBE) Vol 19, No.2

Andri Gunawan. 2017. The Effect of Compensation and Career Development on Job Satisfaction Nurse Which Is Mediated by Work Motivation at Bina Kasih Hospital Pekanbaru. Riau University. Thesis of Riau University, Faculty of Economics, Pekanbaru

Arum Sari and Alwi Suddin. 2015. Effect of Compensation, Work Environment, and Career Development on Job Satisfaction Employee PT. Pegadaian Surakarta Area. University of Slamet Riyadi Surakarta. Journal of Economics and Entrepreneurship Vol. 15 Special Edition April 2015

Aurilia Triani Aryaningtyas and Lieli Suharti. 2013. Employment Engagement as A Mediation Effect of Proactive Personality and Perception of Organizational Support to Job Satisfaction. Journal of Management and Entrepreneurship, Vol.15, No.1, March 2013: 23-32

Defrial. 2006. Correlation Study Between Leadership Style, Organizational Climate, and Compensation with Employee Job Satisfaction at District Secretariat of Kaur Regency. Open University Thesis, Public Administration Studies Program

Ichwan Prastoyo. 2015. The Effect of Career Development, Work Environment, and Organizational Commitment to Job Satisfaction of Hotel Sahid Jaya Solo Employee with Self Confidence as Self-Moderating Variables. Journal of Sainstech Polytechnic of Indonusa Surakarta, Vol 1, Number 3, Year 2015 
Kenny Yulianto Kurniawan. 2015. The Effect of Career Development and Compensation on Employee Job Satisfaction at PT. Parit Padang Global. Petra Christian University. AGORA Vol.3 No. 2, 2015

Kevin F.S Tambengi, Christoffel Kojo, Farlane S Rumokoy. 2016. The Effect of Compensation, Workload, and Career Development on Employee Job Satisfaction At PT. Telekomunikasi Indonesia Tbk, WITEL SULUT. Sam Ratulangi University of Manado. EMBA Journal Vol. December 4, 2016, p. 1088 - 1097

Laysa Aneu, Afrilla Wahda, Agung Wahyu Handaru. 2015. Effect of Career Development and Motivation on Job Satisfaction Employees PT. POS INDONESIA (PERSERO) Bekasi. State University of Jakarta. Journal of Indonesian Science Management Research Vol. 6 No.1, 2015

Retnoningsih, Teguh., Sunuharjo, Bambang Swasto., Ruhana, Ika. 2016. The Effect of Compensation on Job Satisfaction and Employee Performance (Study on Employees of PT PLN (Persero) Distribution East Java Area Malang Journal of Business Administration (JAB) Vo. 35, No. 2, June 2016

Ridwan, Riyadi. 2014. The Influence of Compensation, Job Involvement, and Workload on Job Satisfaction and Its Impact on Employee Performance of Local Government Service Agency of Maternal and Child Government of Aceh Government. Thesis, PostGraduate Program of Syiah Kuala University, Banda Aceh

Rini dan Suhairi Hazizma. 2013. Influence of Employee Empowerment, Self-Finesse, and Job Engagement on Job Satisfaction and Employee Performance (Study on Employees of State Polytechnic of Sriwijaya). Journal of Management and Business of Sriwijaya Vol.11, No.3, September 2013

Rozzaid Yusron, Toni Herlambang, Anggun Meyrista Devi. 2015. Influence of Employee Empowerment, Self-Finesse, and Job Engagement on Job Satisfaction and Employee Performance (Study on Employees of State Polytechnic of Sriwijaya). Journal of Management and Business of Sriwijaya Vol.11, No.3, September 2013...

Terri Aris Archandar. 2010. The Effect of Work Ethics on Job Engagement and Its Implication on Work Commitment, Job Satisfaction, and Performance at Higher Education Institution Employees. Journal of Management and Marketing Services Vol.3 Year 2010

Raharjo, Tri. 2013. Job Involvement Analysis and Empowerment of Job Satisfaction with Mediation of Job Content Plateauing (Study on Village Device in Kandangan Subdistrict of Temanggung Regency). Journal of Economics and Management, Vol.2, No.1 